\title{
Pyrithiobac sodium controls nightshade without long-term effect on cotton
}

\author{
Ron Vargas \ Tomé M. Martin-Duvall $\square$ Steve Wright $\square \quad$ Manuel Jimenez Jr.
}

\begin{abstract}
Nightshades are some of the most difficult weeds to control in Upland Acala varieties of cotton. A herbicide in the newest class of acetolactase synthase inhibitors has been developed for use as a selective over-the-top broadleaf herbicide in cotton. Studies were conducted in Upland Acala cotton varieties in 1991, 1992 and 1993 to evaluate the efficacy of Staple (pyrithiobac sodium) in controlling nightshade. The herbicide was applied as early postemergence, mid-postemergence and sequential applications at rates of $0.25,0.50,0.75,1.0,2.0$ and $3.0 \mathrm{oz}$ of active ingredient per acre (ai/acre). Acceptable nightshade control was achieved at all rates, when applied as a single application or as sequential applications, except for the 0.25 and $0.50 \mathrm{oz}$ ail acre applications. The best control was achieved when the herbicide was applied at rates of 1.0 to $3.0 \mathrm{oz}$ ailacre over the top of cotton in the cotyledon to eight trueleaf stage, with nightshade in the cotyledon to six-leaf stage. Cotton injury symptoms were evident with all treatments at 7 days after application but were nonexistent by 90 days after application. There was no evidence to indicate that pyrithiobac sodium has any longterm effect on cotton growth and development or on cotton lint yield.
\end{abstract}

Because they are tolerant to dinitroaniline herbicides, nightshades (Solanum spp.) are difficult weeds to control in Upland Acala varieties of cotton (Gossypium hirsutum). Nightshades are very competitive with cotton because they germinate and grow rapidly in cool early-season temperatures, when cotton growth and development are extremely slow. Nightshades are considered to be in the "most detrimental to cotton" category (Martin-Duvall 1996). A single black nightshade plant (Solanum nigrum L.) can produce 60,000 to 150,000 seeds per season. A hairy nightshade plant (Solanum sarrachoides) can produce up to 32,000 seeds per season (Kempen 1986). In 1973, nightshade infested 3\% of California cotton; by 1989 , nightshade infested $31 \%$ of the cotton acreage (Keeley and Thullen 1991). Without a 3-week nightshade-free period early in the season, there can be a yield loss greater than 50\% (Vargas et al. 1996a). Therefore early control of nightshade, within 1 to 3 weeks of cotton emergence, and cultivation until layby is critical to producing optimal cotton yields (Keeley and Thullen 1988). Postdirected herbicide applications are not effective because the target weed species are taller than the cotton (Martin-Duvall 1996). Hand hoeing weeds can cost up to $\$ 240$ per acre in severely infested fields, which is not economically feasible for a cotton grower (Vargas and Wright 1994).

The broadleaf herbicide pyrithiobac sodium (Staple) is an acetolactase synthase (ALS) inhibitor. ALS-inhibiting herbicides prevent the development of amino acids, resulting in cessation of plant growth and eventual plant death. Pyrithiobac sodium belongs in the pyrimidinyl thiobenzoate class, which is the newest of the four chemical classes of ALS inhibitors (Jachetta 1996). Pyrithiobac sodium has residual soil activity, which can have adverse effects on crops including sugar beets (Beta vulgaris), onions (Allium cepa), tomatoes (Lycopersicon esculentum) alfalfa (Medicago satira L.) wheat (Triticum spp.), and barley (Hordeum vulgare L.) (Vargas et al. 1996b). However, the herbicide's residual soil activity has no effect on the growth and development of cotton. Cotton is also tolerant to over-the-top applications of the product. Studies conducted by the UC Cooperative Extension over the last few years indicate that pyrithiobac sodium provides effective control of nightshade and can significantly reduce hand-hoeing costs.

\section{Plant damage, nightshade control}

We conducted field studies in 1991 1992 and 1993 to evaluate pyrithiobac sodium for cotton phytotoxicity and control of nightshade. All studies were conducted with Upland Acala 'Maxxa' and 'GC-356' cotton. We used standard cultural practices for cotton production in the San Joaquin Valley, including a preplant application of a dinitroaniline herbicide, nitrogen applications and irrigation, at all test sites. Treatments were replicated three times in a randomized complete block design (RCBD). All treatments were applied over the top of the cotton plants. At various dates after each herbicide application, plots were visually rated for cotton phytotoxicity and nightshade control, using a scale of 0 to 100 , where 0 is no injury or control and 100 is complete plant death. Symptoms of pyrithiobac sodium injury or phytotoxicity on cotton include chlorosis and crinkling of the top two or three true leaves. When yield data was taken, the cotton was either machine or hand harvested and yields were calculated as pounds of cotton lint per acre.

Data collected from all studies were subjected to an analysis of variance using the MSTAT statistical program. Arcsin transformations were performed on all percentage evaluations. Duncan's multiple range test (DMRT) $(P=0.05)$ was used for mean separation from the arcsin- 
transformed data. After the DMRT was run on the means of the data, the arcsin-transformed means of the data were transformed back to normal numbers for reporting.

\section{1 study: GC-356}

A uniform stand of Upland Acala 'GC-356' cotton infested with hairy nightshade was divided into plots of two 38-inch rows by 15 feet and replicated three times in an RCBD. We applied pyrithiobac sodium at $0.25,0.5$, 1.0 and $2.0 \mathrm{oz}$ ai/acre at early postemergence (EP) on June 17, 1991, when the cotton was in the cotyledon to one true-leaf stage and the hairy nightshade was in the two to four true-leaf stage. Half of the EP treatments were followed by a midpostemergence (MP) application at rates of $0.25,0.5,1.0$ and $2.0 \mathrm{oz}$ ai/acre on June 27,1991 , when the cotton was approximately 8 inches tall and had two or three fruiting positions. All herbicide applications received a nonionic surfactant at $0.25 \%$ volume to volume $(\mathrm{v} / \mathrm{v})$. The herbicide was applied at 4 miles per hour (mph) with a $\mathrm{CO}_{2}$ backpack sprayer using 8002 flat fan nozzles with 30 pounds per square inch (psi) pressure delivering a volume of 20 gallons per acre (gpa) of spray solution.

We evaluated pyrithiobac sodium efficacy on nightshade control and cotton phytotoxicity at 7,14 and 54 days after the EP application (DA-EP).

\section{2 study: Maxxa}

We divided a uniform stand of Upland Acala 'Maxxa' cotton infested with black nightshade into plots of two 38-inch rows by 15 feet and replicated them three times in an RCBD. The EP herbicide sprays at $0.75,1.0$, 1.5 and $2.0 \mathrm{oz}$ ai / acre were applied on May 2,1992, when the cotton was in the two true-leaf stage and nightshade was in the cotyledon to two true-leaf stage. We didn't use the 0.25 and 0.5 oz ai/acre rates because results of the 1991 study indicated that they did not provide acceptable control of nightshade. MP applications at 0.75, 1.0, 1.5 and $2.0 \mathrm{oz}$ ai/acre were applied on May 15, 1992, when the cotton was in the four to six true-leaf stage and the nightshade was in the two to six trueleaf stage and 1 to 2 inches tall. Two of the EP applications, one at 0.75 and one at $1.5 \mathrm{oz}$ ai/acre, were followed by MP applications of 0.75 and $1.5 \mathrm{oz}$ ai/ acre respectively.

The herbicide was applied at 4 mph with a $\mathrm{CO}_{2}$ backpack sprayer using 8002 flat fan nozzles with 28 psi pressure delivering a volume of 20 gpa of spray solution. The entire trial site was oversprayed with fluazifop-P (Fusilade) at $0.187 \mathrm{lb}$ ai/acre and a crop oil concentrate at $0.25 \% \mathrm{v} / \mathrm{v}$ on May 21, 1992, for barnyardgrass control.

We evaluated pyrithiobac sodium efficacy on nightshade control and cotton phytotoxicity at 14,21 and 91 DAEP. Selected treatments were hand harvested for cotton lint yield.

\section{3 study: Maxxa}

We divided a uniform stand of Upland Acala 'Maxxa' cotton infested with black nightshade into plots of eight 40 -inch rows by 75 feet and replicated them three times in an RCBD. EP applications of Staple were applied at $1.0,1.5$ and $3.0 \mathrm{oz}$ ai/acre on May 6, 1993 , when the cotton was in the cotyledon to one true-leaf stage and the nightshade was in the cotyledon to three true-leaf stage. We included a single $3.0 \mathrm{oz}$ ai/acre treatment as a comparison against the EP $1.5 \mathrm{oz}$ ai/ acre followed by the MP $1.5 \mathrm{oz} \mathrm{ai} /$ acre treatment. The MP applications were applied at 1.0 and $1.5 \mathrm{oz}$ ai/acre on May 27, 1993, when the cotton was 6 inches tall with the nightshade ranging from 4 to 10 true leaves. A nonionic surfactant at $0.25 \% \mathrm{v} / \mathrm{v}$ was included with all treatments. The herbicide was applied with a tractor-drawn sprayer using twin jet 60-4003 even stainless flat fan nozzles at 30 psi delivering a volume of 20 gpa of spray solution.

We evaluated pyrithiobac sodium efficacy on nightshade control and cotton phytotoxicity at 7, 14, 21 and 28
Staple herbicide applied over-the-top provided $100 \%$ nightshade control in cotton. Shown here, a field 50 days after a $1.0 \mathrm{oz}$. ai/acre application. Untreated area is in middle ground.

DA-EP and for nightshade control at 7 , $14,21,28$ and 50 DA-EP. The treatments were machine harvested for cotton lint yield on Oct. 29, 1993.

\section{Cotton phytotoxicity}

At 7 DA-EP, all pyrithiobac sodium rates exhibited significantly greater phytotoxicity than the untreated control, but were not significantly different from each other in all 3 years. In 1993, cotton phytotoxicity was slightly greater at comparable rates than in 1991 and 1992. At 14 DA-EP, all rates continued to exhibit significantly greater injury than the untreated control in all 3 years of the study. In 1991, $0.25 \mathrm{oz}$ ai/acre exhibited the least cotton injury at $14 \mathrm{DA}-\mathrm{EP}$ (table 1). The greatest injury was exhibited by the single 0.5 and $1.0 \mathrm{oz}$ ai/acre rates and sequential $0.5,1.0$ and $2.0 \mathrm{oz}$ ai/acre rates, which were all significantly greater than all other rates and the untreated control. There were no significant differences between all rates at the 14 DA-EP in 1992 (table 2). However, in 1991 and 1993 cotton phytotoxicity was similar at the single 1.0 and sequential $1.0 \mathrm{oz}$ ai/acre rates (tables 1 and 3). At the 28 to 54 DA-EP applications, cotton was outgrowing the phytotoxic effects of the herbicide applied at all single rates in all 3 years. In 1992 and 1993 , at 28 DA-EP, the single EP $0.75,1.0,1.5,2.0$ and $3.0 \mathrm{oz}$ ai/acre rates exhibited no cotton in- 
TABLE 1. The effects of pyrithiobac sodium (Staple) herbicide at various rates and timings on cotton phytotoxicity and control of hairy nightshade in the San Joaquin Valley, 1991

\begin{tabular}{|c|c|c|c|c|c|c|c|c|}
\hline \multirow[b]{3}{*}{ Treatment } & \multirow{2}{*}{\multicolumn{2}{|c|}{ Application rate }} & \multicolumn{3}{|c|}{ Cotton phytotoxicity } & \multicolumn{3}{|c|}{ Nightshade control } \\
\hline & & & \multicolumn{6}{|c|}{ Days after early postemergence application } \\
\hline & $\mathrm{EP}^{*}$ & MPt & 7 & 14 & 54 & 7 & 14 & 54 \\
\hline \multicolumn{9}{|c|}{ oz ai/acre } \\
\hline Pyrithiobac sodium & 0.25 & - & 13 ał & $6 \mathrm{c}$ & $0 \mathrm{~d}$ & 33 a & $47 \mathrm{~b}$ & $0 \mathrm{~g}$ \\
\hline Pyrithiobac sodium & 0.50 & - & $13 a$ & $13 a b$ & $0 \mathrm{~d}$ & $30 a$ & $43 \mathrm{bc}$ & $27 f$ \\
\hline Pyrithiobac sodium & 1.00 & - & $10 \mathrm{a}$ & $16 a b$ & $0 \mathrm{~d}$ & $29 a$ & $47 \mathrm{~b}$ & $60 \mathrm{de}$ \\
\hline Pyrithiobac sodium & 2.00 & - & $10 \mathrm{a}$ & $10 \mathrm{bc}$ & $2 c$ & $40 \mathrm{a}$ & $43 \mathrm{bc}$ & $81 \mathrm{bc}$ \\
\hline Pyrithiobac sodium & 0.25 & 0.25 & $10 \mathrm{a}$ & $10 \mathrm{bc}$ & $13 b$ & $30 \mathrm{a}$ & $40 \mathrm{c}$ & $53 e$ \\
\hline Pyrithiobac sodium & 0.50 & 0.50 & $16 \mathrm{a}$ & $16 a b$ & $13 b$ & $30 \mathrm{a}$ & $43 \mathrm{bc}$ & $70 \mathrm{~cd}$ \\
\hline Pyrithiobac sodium & 1.00 & 1.00 & $16 \mathrm{a}$ & $13 a b$ & $30 \mathrm{a}$ & $30 \mathrm{a}$ & $43 \mathrm{bc}$ & $83 b$ \\
\hline Pyrithiobac sodium & 2.00 & 2.00 & $13 \mathrm{a}$ & $20 \mathrm{a}$ & $30 \mathrm{a}$ & $33 \mathrm{a}$ & $53 \mathrm{a}$ & 95 a \\
\hline Untreated control & - & - & $\mathrm{Ob}$ & $0 \mathrm{~d}$ & $0 \mathrm{~d}$ & $\mathrm{Ob}$ & $0 \mathrm{~d}$ & $\mathrm{Og}$ \\
\hline Percent CV at .05 & & & 17 & 20 & 28 & 16 & 6 & 13 \\
\hline
\end{tabular}

* EP Early postemergence application

$\dagger$ MP Mid-postemergence application

$\ddagger$ Numbers in a column followed by the same letter are not significantly different (Duncan's multiple range test, $\mathrm{P}=0.05$ ) jury. In 1991, at 54 DA-EP, the single EP $0.25,0.5$ and $1.0 \mathrm{oz}$ ai/acre rates were not significantly different than the untreated control for cotton phytotoxicity. The sequential $0.25,1.0$ and $1.5 \mathrm{oz}$ ai/acre rates exhibited significantly greater phytotoxicity than the untreated control or the EP application.

In 1991 and 1993, cotton injury was significantly greater with sequential rates at 28 and 54 DA-EP compared to the single EP application or untreated control. The greatest increase in injury occurred at sequential rates of 1.0, 1.5 and $2.0 \mathrm{oz}$ ai/acre. At $28 \mathrm{DA}-\mathrm{EP}$, in 1993 , the $1.5 \mathrm{oz}$ ai/acre rate followed by an additional $1.5 \mathrm{oz}$ ai/acre rate exhibited $33 \%$ phytotoxicity, which was significantly greater than all rates and the untreated control. In 1991, sequen-

TABLE 2. The effects of pyrithiobac sodium (Staple) herbicide at various rates and timings on cotton phytotoxicity, control of black nightshade and seed cotton yield in the San Joaquin Valley, 1992

\begin{tabular}{|c|c|c|c|c|c|c|c|c|c|c|}
\hline \multirow[b]{3}{*}{ Treatment } & & & \multicolumn{3}{|c|}{ Cotton phytotoxicity } & \multicolumn{4}{|c|}{ Nightshade control } & \multirow[b]{3}{*}{ Lint yield } \\
\hline & \multicolumn{2}{|c|}{ Application rate } & \multicolumn{7}{|c|}{ Days after early postemergence application } & \\
\hline & EP* & MP† & 7 & 14 & 28 & 7 & 14 & 21 & 28 & \\
\hline & \multicolumn{2}{|c|}{ oz ailacre } & & & & $\ldots . . \%$. & $\cdots$ & & $\ldots . .$. & $\mathrm{lb} / \mathrm{ac}$ \\
\hline Pyrithiobac sodium & 0.75 & - & 16 ał & 5 a & $0 \mathrm{ab}$ & $23 \mathrm{a}$ & $67 \mathrm{a}$ & $77 \mathrm{ab}$ & $81 \mathrm{a}$ & \\
\hline Pyrithiobac sodium & 0.75 & 0.75 & $13 \mathrm{a}$ & $1 \mathrm{a}$ & $6 a b$ & $23 \mathrm{a}$ & 67 a & $81 a b$ & $81 \mathrm{a}$ & \\
\hline Pyrithiobac sodium & - & 0.75 & - & - & $9 a b$ & - & - & 67 bc & $73 a$ & \\
\hline Pyrithiobac sodium & 1.0 & - & $13 \mathrm{a}$ & $1 \mathrm{a}$ & $\mathrm{OC}$ & $23 a$ & $67 \mathrm{a}$ & $78 a b$ & $84 a$ & \\
\hline Pyrithiobac sodium & - & 1.0 & - & - & $10 \mathrm{a}$ & - & - & 67 bc & $73 \mathrm{a}$ & \\
\hline Pyrithiobac sodium & 1.5 & - & $16 \mathrm{a}$ & $16 a$ & $2 \mathrm{bc}$ & $23 a$ & $67 \mathrm{a}$ & $84 a$ & $84 a$ & 1,657 a \\
\hline Pyrithiobac sodium & - & 1.5 & - & - & $10 \mathrm{a}$ & - & - & $60 \mathrm{c}$ & $70 a$ & $1,491 \mathrm{a}$ \\
\hline Pyrithiobac sodium & 1.5 & 1.5 & $16 a$ & $13 a$ & $5 a b$ & $20 a$ & $63 a$ & $78 a b$ & $81 a$ & $1,599 a$ \\
\hline Pyrithiobac sodium & 2.0 & - & $19 a$ & $7 a$ & $\mathrm{Oc}$ & $23 \mathrm{a}$ & $67 \mathrm{a}$ & $79 a b$ & $80 a$ & \\
\hline Pyrithiobac sodium & - & 2.0 & - & - & $9 a b$ & - & - & $70 \mathrm{bc}$ & $78 \mathrm{a}$ & \\
\hline Untreated control & - & - & $\mathrm{Ob}$ & $0 \mathrm{a}$ & $\mathrm{OC}$ & $0 \mathrm{~b}$ & $\mathrm{Ob}$ & $0 \mathrm{~d}$ & $\mathrm{Ob}$ & $979 \mathrm{~b}$ \\
\hline Percent $\mathrm{CV}$ at .05 & & & 25 & 67 & 46 & 15 & 8 & 9 & 10 & 10 \\
\hline
\end{tabular}

* EP Early postemergence application

$†$ MP Mid-postemergence application

¥ Numbers in a column followed by the same letter are not significantly different (Duncan's multiple range test, $P=0.05$ )

TABLE 3. The effects of pyrithiobac sodium (Staple) herbicide at various rates and timings on cotton phytotoxicity, control of black nightshade and seed cotton yield in the San Joaquin Valley, 1993

\begin{tabular}{|c|c|c|c|c|c|c|c|c|c|c|}
\hline \multirow[b]{3}{*}{ Treatment } & & & \multicolumn{3}{|c|}{ Cotton phytotoxicity } & \multicolumn{4}{|c|}{ Nightshade control } & \multirow[b]{3}{*}{ Lint yield } \\
\hline & \multicolumn{2}{|c|}{ Application rate } & \multicolumn{7}{|c|}{ Days after early postemergence application } & \\
\hline & $\mathrm{EP}^{\star}$ & MP† & 7 & 14 & 28 & 7 & 14 & 28 & 50 & \\
\hline & \multicolumn{2}{|c|}{ oz ai/acre } & 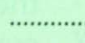 & & & $\ldots \%$. & & 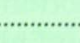 & ......... & $\mathrm{Ib} / \mathrm{ac}$ \\
\hline Pyrithiobac sodium & 1.0 & - & $23 \mathrm{a}$ & $13 c$ & $\mathrm{Oc}$ & $40 \mathrm{a}$ & $54 \mathrm{a}$ & 97 a & $94 \mathrm{~b}$ & $2,130 \mathrm{a}$ \\
\hline Pyrithiobac sodium & 1.5 & - & $33 \mathrm{a}$ & $30 a b$ & $\mathrm{OC}$ & 47 a & $63 \mathrm{a}$ & $100 \mathrm{a}$ & 99 a & 2,099 a \\
\hline Pyrithiobac sodium & 3.0 & - & $37 \mathrm{a}$ & $23 a b c$ & $\mathrm{OC}$ & $40 \mathrm{a}$ & $50 \mathrm{a}$ & 99 a & $98 a b$ & 2,135 a \\
\hline Pyrithiobac sodium & 1.0 & 1.0 & $25 \mathrm{a}$ & $19 \mathrm{bc}$ & $23 b$ & $33 \mathrm{a}$ & 57 a & $100 \mathrm{a}$ & $100 \mathrm{a}$ & $2,125 \mathrm{a}$ \\
\hline Pyrithiobac sodium & 1.5 & 1.5 & $43 a$ & $33 \mathrm{a}$ & $33 a$ & $43 a$ & $63 \mathrm{a}$ & $100 a$ & $100 \mathrm{a}$ & $2,108 \mathrm{a}$ \\
\hline Untreated control & - & - & $\mathrm{Ob}$ & $0 \mathrm{~d}$ & $O C$ & $\mathrm{Ob}$ & $\mathrm{Ob}$ & $\mathrm{Ob}$ & $\mathrm{OC}$ & $2,162 \mathrm{a}$ \\
\hline Percent CV at .05 & & & 22 & 7 & 23 & 17 & 14 & 9 & 8 & 5 \\
\hline
\end{tabular}

* EP Early postemergence application

† MP Mid-postemergence application

$\ddagger$ Numbers in a column followed by the same letter are not significantly different (Duncan's multiple range test, $P=0.05$ ) 
tial applications at 1.0 and $2.0 \mathrm{oz}$ ai/ acre exhibited significantly greater phytotoxicity at $30 \%$ injury than all other rates and the untreated control.

In all 3 years of the study, most cotton phytotoxicity symptoms were gone by 28 days after application, and at 90 days after application there was no indication of injury, with all single and sequential rates being significantly the same as the untreated control.

\section{Nightshade control}

At 7 DA-EP, nightshade control ranged from $20 \%$ to $47 \%$. Nightshade control of less than $80 \%$ is considered to be unacceptable control. All single and sequential treatments of pyrithiobac sodium provided significantly greater control than the untreated control and were not significantly different from one another in all 3 years. At $14 \mathrm{DA}$ EP, control increased to a range of $40 \%$ to $67 \%$. Again, in all 3 years of the study, all single and sequential rates provided significantly greater control than the untreated control. In 1991, the sequential $2.0 \mathrm{oz}$ ai/acre rate provided significantly greater control than all other single or sequential rates. Unacceptable control was exhibited at 54 DA-EP at the 0.25 and $0.5 \mathrm{oz}$ ai/acre rates, with $0 \%$ and $27 \%$ control respectively. These rates were significantly less than all other rates. Because of the unacceptable control, the .25 and 0.5 $\mathrm{oz}$ ai/acre rates were eliminated from the last 2 years of the study.

At 28 to 54 DA-EP, acceptable control was achieved with single EP rates of $0.75,1.0,1.5,2.0$ and $3.0 \mathrm{oz}$ ai/acre and sequential rates of $0.75,1.0,1.5$ and $2.0 \mathrm{oz}$ ai/acre, with control ranging from $81 \%$ to $100 \%$. In $1993,100 \%$ control was achieved at $28 \mathrm{DA}-\mathrm{EP}$, with a single EP $1.5 \mathrm{oz} \mathrm{ai}$ /acre and sequential 1.0 and $1.5 \mathrm{oz}$ ai/acre rates. However, these treatments did not provide significantly greater control than all other treatments in 1993. In 1992 and 1993 the sequential treatments did not provide significantly greater nightshade control than single treatments, although in 1991 the sequential $2.0 \mathrm{oz}$ ai/acre rate provided significantly greater control than all other single or sequential treatments.

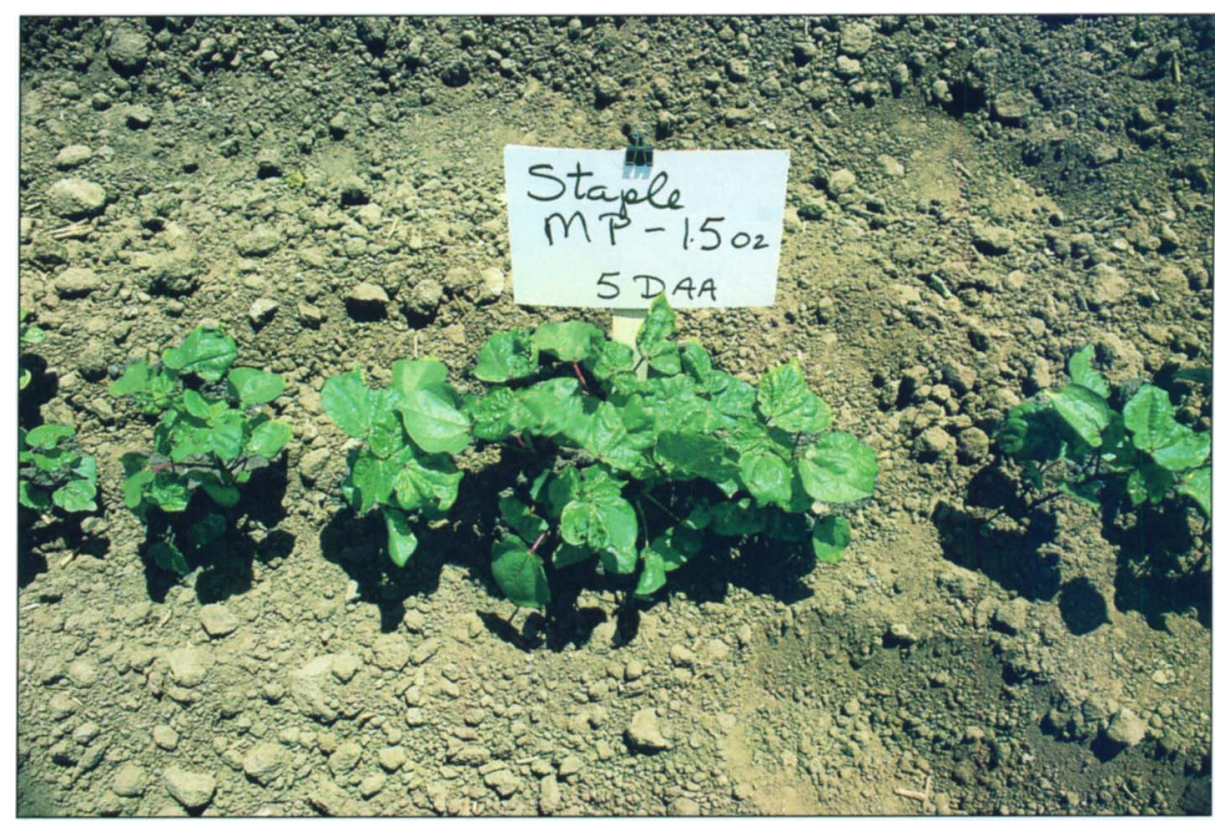

Over-the-top herbicide sprays caused cotton leaves to yellow, bronze and crinkle, but the injury symptoms usually disappeared within 28 days.

\section{Cotton lint yields}

In 1992 and 1993, we collected yield data to determine the effect of pyrithiobac sodium on cotton lint yields. In 1992, the single $1.5 \mathrm{oz}$ ai/ acre at both EP and MP, the $1.5 \mathrm{oz}$ ai/acre sequential and the untreated control were selected to compare yield. There were no significant differences in cotton lint yield between the single and sequential treatments, with yields ranging from 1,491 to 1,652 pounds of lint per acre. All treated plots produced significantly greater yields than the untreated control, at 979 pounds of lint per acre. The significant difference in yield between the untreated control and the treated plots was due to the extremely high nightshade population in the study area. The $34 \%$ to $41 \%$ reduction in cotton lint yield in the untreated control due to the season-long nightshade infestation indicates the competitive effect that nightshade can have on cotton. There were no significant differences in lint yields in 1993 between treatments or the untreated control, with yields ranging from 2,099 to 2,162 pounds of lint per acre. There was no difference between the treatments and the untreated control in 1993 because after the 50 DA-EP evaluation the untreated control plots were hand hoed, which reduced the influence of nightshade on cotton growth, development and lint yield.

\section{Excellent nightshade control}

The herbicide pyrithiobac sodium (Staple) can be sprayed over the top of cotton without any long-term adverse effects on the cotton. In the short term, symptoms exhibited by cotton include chlorosis and crinkling of the upper leaves. However, most phytotoxicity symptoms were gone by 28 days after application, and at 90 days after application there was no indication of injury to the cotton. These studies indicate that early cotton phytotoxicity has no significant long-term effect on growth, development or lint yield.

Pyrithiobac sodium, in combination with a nonionic surfactant, provides excellent control of nightshade. These studies show that the best control is achieved when it is applied at rates of 1.0 to $3.0 \mathrm{oz} \mathrm{ai} /$ acre over the top of cotton in the cotyledon to eight trueleaf stage, with nightshade in the cotyledon to six leaf stage. These studies further show that there is no advantage to sequential treatments for nightshade control.

Because pyrithiobac sodium has no activity on grass species and weeds in the Chenopodiaceae (lambsquarters) family, a dinitroaniline such as trifluralin (Treflan) or pendimethalin (Prowl) should be applied to obtain 
control of these weed species.

Pyrithiobac sodium is an ALS inhibitor so nightshade growth is quickly arrested and ultimate plant death is slow, occurring over a period of 3 to 4 weeks. Cultivation enhances control by throwing dirt to the base of the cotton plant, covering the affected nightshade plants.

Future research will be conducted to address timing and rates for effective use in Pima (Gossypium barbadense) cotton and to determine the extent of antagonism when Staple is tank mixed with the selective postemergence grass herbicides fluazifop-P (Fusilade), sethoxydim (Poast) and clethodim (Prism).

R. Vargas is Farm Advisor and T.M. Martin-Duvall is Staff Research Associate, UC Cooperative Extension, Madera County; S. Wright is Farm Advisor and M. Jimenez Jr. is Staff Research Associate, UCCE, Tulare County.

\section{References}

Jachetta J. 1996. Amino acid inhibition herbicides. California Weed Science Society Proc 48:135-41. Jan 21-23, 1996. Sacramento, CA.

Keeley PE, Thullen RJ. 1988. Growth and early production of black nightshade in cotton. California Weed Science Society Proc 40:220-1. Jan 18-21, 1988. Sacramento, CA.

Keeley PE, Thullen RJ. 1991. Biology and control of black nightshade (Solanum nigrum) in cotton (Gossypium hirsutum). Weed Technology 5:713-22

Kempen HM. 1986. Nightshade, cotton's no. 1 enemy. California Weed Science Society Proc 38:136-44. Jan 27-30, 1986. Fresno, CA.

Martin-Duvall TM. 1996. Effects of adjuvants and Fusilade on the efficacy of Staple on nightshade in cotton. Fresno, CA: California State University Fresno.

Vargas RN, Fischer WB, Kempen HM, Wright SD. 1996. Cotton weed management. Cotton Production Manual. University of California, DANR, Publication \#3352. p. 187.

Vargas RN, Wright SD. 1994. Nightshade control with pyrithiobac sodium (Staple) in California cotton. Challenging the Future. World Cotton Conference Proc 1:191-3. Feb. 14-17, 1994. Brisbane, Australia

Vargas RN, Wright SD, Martin-Duvall TM, Jimenez Jr. M. 1996a. Control of nightshade in cotton with Staple (pyrithiobac sodium) and its effect on rotational crops in California. Western Society of Weed Science Proc 49:90. Mar 11-14, 1996 Albuquerque, NM.

Vargas RN, Martin-Duvall TM, Wright SD, Jimenez Jr. M. 1996b. Staple: Is it the silver bullet for cotton. California Weed Science Society Proc 48:100-6. Jan 22-24, 1996. Sacramento, CA.

\title{
Curly top virus found in perennial shrubs in foothills
}

\author{
R. Michael Davis $\square$ Heping Wang $\square$ Bryce W. Falk \\ Joe J. Nunez
}

Beet curly top geminivirus damages numerous crops, including beans, beets, spinach, peppers, melons and tomatoes. Both the virus and its vector, the beet leafhopper, overwinter in the foothills surrounding the Central Valley. The known host range of the virus is now recognized to include many native and introduced perennial shrubs in the foothills. This is the first reported detection of the virus in plants in the families Ephedraceae, Rhamnaceae and Salicaceae.

In North America, the beet curly top geminivirus is transmitted only by the beet leafhopper. Both the disease and the leafhopper have extensive host ranges and are widespread throughout the western United States. If susceptible crops are visited by large numbers of viruliferous leafhoppers, the disease can cause crop losses near $100 \%$ in individual fields. The epidemiology of curly top disease - so named because of the bunchy, twisted foliage characteristic of many infected crop plants - is complex and disease control is difficult.

The native vegetation of California does not allow the buildup of large populations of the beet leafhopper, Circulifer tenellus, but several generations are produced on introduced mustards, Russian thistle, and other annual weeds over the summer. During this time the beet leafhopper may visit crop plants and transmit beet curly top geminivirus (BCTV) while feeding, even though the crop may not be a preferred host (e.g., tomato). As crops and annual weeds dry in the autumn, the beet leafhopper moves back to breeding areas in the foothills and overwinters on perennials. When spring rains germinate various annuals including mustards, peppergrass and filaree, leafhoppers congregate and lay eggs on these plants on warm, sunny slopes. As these hosts mature and dry, the next generation of beet leafhoppers migrates to agricultural lands to feed on crops and nearby weeds such as Russian thistle (Bennett 1971). At some point in its life, the insect may feed on BCTV-infected plants and acquire the virus, which it can then transmit for the remainder of its life.

The purpose of this study was to determine if native and introduced

\section{Editor's note}

\begin{abstract}
"New pests and plant diseases," survey articles describes new pests and diseases of statewide significance. We are publishing this new research section as an experiment. In the last 3 years, California Agriculture has not printed articles of this nature because they do not meet the test of containing 2 years of experimental data. However, we feel that these articles may provide important information to our readers. Please let us know what you think about this, and whether articles of this nature present information important to you.
\end{abstract}

